Collection Management, 2010, vol.35, no.3 \& 4, p.208-221.

ISSN: 0146-2679 (print) 1545-2549 (online)

DOI: $10.1080 / 01462679.2010 .486968$

http://www.tandfonline.com/

http://www.tandfonline.com/loi/wcol20

http://www.tandfonline.com/toc/wcol20/35/3-4

(C) 2010 Taylor \& Francis Group, LLC

\title{
Patron-Initiated Collection Development: Progress of a Paradigm Shift
}

\author{
Dracine Hodges, Cyndi Preston, and Marsha J. Hamilton
}

This article discusses a paradigm shift from librarian-mediated collection development to patron-initiated selection of library materials. The authors report on two programs at The Ohio State University Libraries (OSUL): an interlibrary loan purchase-on-demand program and two tests of ebrary's patron-driven acquisitions program, in which patron usage triggered behind-the-scenes purchase of e-books. Results of the tests were analyzed by user activity, subject area, publisher type and level, and imprint date. OSUL and OhioLINK consortium holdings were reviewed to evaluate availability, duplication, and circulation of titles purchased by patrons. OSUL subject librarians were polled for comments on patron-selected titles and the funding implications of patron-driven selection. The authors discuss changes in the philosophy of collection development, and the role of patrons and collection development librarians in the evolving e-book environment in academic libraries.

\section{FROM LIBRARIAN SELECTION TO LIBRARIAN-MEDIATED PATRON SELECTION}

Academic libraries have traditionally allowed patron input on purchasing decisions, from the suggestion box to online request forms, but the authority for collection development ultimately resided with librarians. Technology and economic factors have positioned a paradigm to shift. This article examines the progression from librarian-mediated to patron-initiated collection development and the factors driving it. The shift will be illustrated with programs at the Ohio State University Libraries (OSUL).

During the expansion of Ohio State University following World War II, with classrooms overflowing with GI Bill students, library acquisitions funds increased along with the number of subject specialists hired to build the collections. The postwar ideal was to build a research library to meet the needs of existing and future patrons. This was the "just-in-case" model of collection development. It was the bibliographer's job to identify the best materials, and the job of the acquisitions department to acquire them. Items requested by patrons could be ordered, but the bibliographer strove to anticipate the needs of faculty and students, by being familiar with their research and classes, and to purchase titles in advance of need.

As decades passed, economic factors exerted greater pressure on this model. Monumental collection building as a societal good or as a marker of university quality was no longer considered economically feasible, due to price inflation for print and electronic products, the increase in the production of scholarly material, and the increased cost of storing materials that might never circulate. Some libraries adopted the new paradigm of "justin-time" (JIT) inventory, implemented in the Japanese auto industry in the 1980s. In the JIT model, a large inventory of parts is viewed as waste. Instead, only the minimal inventory is maintained on site. In a library context, inventory consists of materials purchased in anticipation of future need. A large inventory of materials that 
never circulate is viewed as waste because it costs money to maintain and does not produce a product. This problem can be avoided by not buying library materials until there is a patron request. This JIT paradigm was tested in the 1990s through interlibrary loan (ILL) purchase-on-demand programs.

\section{INTERLIBRARY LOAN PURCHASE ON DEMAND: ILPOD AT OSUL}

In 1990, Bucknell University began purchasing books requested by patrons through ILL if it was faster or more economical than borrowing. The pilot was so successful that Bucknell's ILL department was incorporated into their acquisitions department (Perdue and Van Fleet 1999; Ward et al. 2003). Other libraries adopted this model under various names, e.g., purchase on demand, direct purchase, just-in-time acquisitions, patron-demand acquisitions, and patron-initiated collection development. All libraries established criteria to determine which items should be purchased or borrowed. These criteria generally included cost, publication date, availability to borrow or purchase the item, turnaround time, level of scholarship, and the borrower's status (Zopfi-Jordan 2008, 389; Allen et al. 2003; Ward 2002, 95). Librarians continued to mediate the process; not all patron requests were turned into purchases.

OSUL's interlibrary loan purchase on demand (ILPOD) evolved from a 2008 test called "Search OSU and Beyond," in which the OSUL homepage search box directed queries to the WorldCat database. OSUL and OhioLINK holdings were displayed at the top of the search results. Because patrons were searching a larger database, they were more likely to retrieve results, but fewer of the items were held by OSUL or by OhioLINK consortium members. A link to ILL prompted patrons to request non-OhioLINK titles. As soon as the "Search OSU and Beyond" service started, OSUL's head of interlibrary services noticed an increase in ILL requests, especially for new publications, textbooks, and forthcoming items found in WorldCat.

The OSUL head of interlibrary services worked with the monographs department, and later with a subject librarian who reviewed requests, to establish an ILL purchase-on-demand program. The program was not advertised to patrons. Instead, patrons received an e-mail saying the item they had requested through ILL was being purchased and would soon be available for their use. Requests were rush-ordered and monographs department staff e-mailed the patron when the item arrived. The speed of supply and personal notification made this ongoing program popular with patrons.

The librarian responsible for mediating ILPOD requests used her judgment before forwarding a title for ordering. The general criteria she established included the following:

- $\$ 200$ price limit

- Publication date in the last two years

- Preference for scholarly material

- Items that OSUL was unable to borrow

- Media and foreign language requests were allowed

- Textbooks were allowed, which supplemented the OSUL Textbook Project, with a budget of $\$ 10,000$ per year to purchase textbooks to be put on closed reserve

- Computer manuals, popular culture materials, and fiction were excluded unless the patron indicated the item was needed for classroom or research purposes

- Exceptions were made as judgment calls 
In the 22 months between March 2008 and December 2009, the ILPOD liaison fielded 2,146 requests forwarded from ILL, resulting in 560 purchases (26\% of ILL titles referred) at a cost of $\$ 68,297$. ILPOD was funded centrally, not by subject funds. Among the items not purchased were 68 not-yet-published titles, which were referred to subject specialists, and 121 out of 243 requested textbooks. Other items were borrowed through ILL. The most frequent beneficiaries of ILPOD were graduate students (47\%), followed by undergraduates (25\%), faculty (20\%), and staff (8\%). ILPOD purchases averaged 16 circulations: a high number, considering the oldest item had been owned for only 22 months. The highest circulation was a textbook, soon placed on closed reserve, with 151 circulations. As reported by other libraries, ILPOD requests appear to circulate at a higher rate than the general collections (Comer and Lorenzen 2005; Chan 2004). The paradigm at OSUL is slowly shifting from just-in-case collection development by librarians to more JIT librarian-mediated purchases that respond to patron requests at point of need. The next phase in this paradigm shift involves the introduction of unmediated patron-initiated collection development.

\section{EBRARY PILOT PROJECTS AT OSUL}

2008 was a watershed year for integrating e-book acquisitions into mainstream academic library workflows. In that year, the two major book vendors, Blackwell and YBP, adapted their ordering databases, Collection Manager and GOBI, respectively, to supply e-books from aggregators OCLC NetLibrary, EBL, and ebrary. This was a welcome alternative to negotiating separate licenses with individual publishers. These GOBI e-book orders followed the traditional model of selection by librarians, although some e-books were purchased for the ILPOD program based on patron requests.

Doug Way briefly summarized the situation faced by many libraries: “. . . in the past six years only $31 \%$ of the library's book collection has circulated. At the same time there has been a dramatic increase in the use of ILL. ... Seeing the use of ILL as an indicator of unmet demand, the library began to look toward patron-initiated collecting as a way to identify works that would enhance the library's collections" (Way 2009, 303). OSUL was also interested in meeting patron needs while increasing the number of times a title circulated.

The monographs department received administrative approval in 2009 to test ebrary's new patron-driven access service and established a deposit account of $\$ 25,000$ with ebrary. In September 2009, ebrary provided approximately 93,000 e-book titles in an Excel spreadsheet that listed the ebrary ID number, title, author, publisher, content owner, LC call number, print ISBN, eISBN, two non-LC subject headings, and list price. The head of the monographs department used criteria recommended by the OSUL Collections Advisory Council (CAC) to reduce the number of records. The criteria excluded the following:

- Pre-2007 imprints

- List price over $\$ 299.99$

- Forty publishers (not wanted or already acquired via standing orders or OhioLINK)

- Twenty subject headings (e.g., Juvenile Fiction, Self-Help)

- Computer manuals

- Technical areas in law

- Foreign language texts with no English language content

- Fiction (literary fiction and short stories were included) 
Applying these criteria reduced the spreadsheet to fewer than 16,000 titles. The spreadsheet was returned to ebrary staff along with detailed criteria for types of materials to be excluded. Ebrary used this profile, similar to that of an approval plan, to generate a file of full MARC records, and OSUL staff downloaded the records from ebrary's Web site. This group of about 16,000 librarian-mediated e-books constituted the Test 1 database.

The loading of Test 1 records into the OSUL catalog took about one week. First, a load table was created in OSUL's Innovative Interfaces, Inc. Millennium system so an item record with fixed field data would be attached to the incoming bibliographic records. Before the load, MarcEdit was used to move and add data. The URL from the MARC 856 was moved to the local 956 field. Records were coded to display in the OSUL catalog but were not contributed to OhioLINK or WorldCat. A 910 field was added to identify test records, including the date of the load. Test 1 records in the public catalog looked identical to other e-book holdings, except that they lacked a call number. Patrons clicked on a "Connect to Resource" link and went directly to the full text of the e-book hosted on ebrary's server, identical to the procedure and display of other ebrary e-books owned by OSUL. There was no indication that the e-book was part of a test or that patron use would trigger a purchase. The test was not advertised to patrons. Test 1 went live October 25, 2009. OSUL librarians hoped the $\$ 25,000$ deposit would be sufficient for the full 18-week test, so everyone was surprised when ebrary staff notified OSUL that the deposit had been expended in a little over four weeks. Statistics supplied by ebrary showed that patrons began triggering purchases on the first day, which was a Sunday. During Test 1, ebrary set OSUL's trigger for purchase at ten "activities." An "activity" occurred when a patron views a page not previously viewed or prints or copies any page of the e-book. Purchases ranged from a daily low of 5 to a high of 22 , but averaged 12 per day at a cost of about $\$ 1,150$ per day. Test 1 was frozen at the end of 37 days, on November 30, 2009. Patrons had triggered a total of 450 titles for purchase, and additional funds were needed to retain all the triggered titles. At OSUL's request, ebrary turned off access to non-purchased titles, and OSUL suppressed the unpurchased MARC records from public view.

The head of the monographs department and members of CAC reviewed the patron-driven access purchases. A question soon arose concerning imprint dates; several of the titles purchased were older than 2007. ebrary staff discovered that metadata supplied by some publishers listed the e-book release date, not the date of the original content. Publishers had mined their backlists for new e-books; patrons, who could see accurate imprint dates in the MARC records, had purchased titles published twenty or more years before the 2007 through 2009 profile dates. ebrary agreed to "unpurchase" these titles after a list was provided.

The ebrary representatives were helpful in resolving each issue with OSUL, discussing what was learned from Test 1 in light of future options. One discussion was how to restrict costs by further reducing the overall number of patron-driven access titles to exclude lower-use items that still triggered a purchase. To make that reduction, it was necessary to understand which e-books would be used most heavily by patrons and would thus be the most cost-effective purchases. Were the criteria used too broad? Should OSUL have already acquired these titles? Would librarians have purchased these titles with their subject funds? If so, should a portion of acquisitions funds be shifted to patron-initiated purchases? Or were patrons triggering titles that were unsuitable for an academic library? Data were analyzed to answer these questions. 


\section{USE OF TEST 1 AND TEST 2 E-BOOKS BY SUBJECT}

Although a program offering fewer patron-driven access titles would help limit fiscal liability, it would also decrease patron access to e-book content. The ebrary staff offered an interesting alternative. Why not test an unmediated group of titles to see whether patron use differed substantially? OSUL and ebrary agreed that this second test of patron activity would use ebrary's Academic Complete database, representing about 43,000 e-books with imprint dates ranging from 1866 to 2009. This group of records was called Test 2 and ran for 37 days to match the length of Test 1 . ebrary provided the MARC records, which were again edited and loaded into the OSUL catalog for patron discovery. At the end of Test 2, ebrary provided raw data for the authors to analyze.

Some OSUL librarians assumed that patrons in the sciences were more apt to use e-books than were patrons in the humanities or social sciences. In Test 1, patrons triggered more science titles $(40 \%)$ than social science (33\%) or humanities titles (27\%). Test 1, however, involved a librarian-mediated selection of about 16,000 titles from a list of 93,000 titles. It is possible the selection process favored the inclusion of more science and social science titles. The unmediated file in Test 2 showed a different pattern. A total of 1,242 of the 43,000 titles in Test 2 were viewed by patrons. Social science titles were viewed most heavily (39\%), followed by humanities (37\%), and sciences (24\%). It was not possible to analyze the huge record sets to see whether these differences were a function of how many titles in each subject were added to the catalog. Preliminary findings, however, show that OSUL patrons in the humanities and social sciences were as apt to use e-books as patrons in the sciences.

TABLE 1 Test 1 Titles Triggered for Purchase by Subject

\begin{tabular}{|l|r|r|}
\hline Subjects Purchased & No. of Titles Purchased & \% of All Titles \\
\hline Health Sciences & 52 & 11.6 \\
\hline Business/Economics & 46 & 10.2 \\
\hline Psychology & 30 & 6.7 \\
\hline Education/Physical Education & 27 & 6.0 \\
\hline Engineering & 23 & 5.1 \\
\hline Agriculture/Natural Resources & 22 & 4.9 \\
\hline History & 19 & 4.2 \\
\hline English & 18 & 4.0 \\
\hline Biological Sciences & 15 & 3.3 \\
\hline Mathematics/Statistics & 15 & 3.3 \\
\hline Sociology/Social Work & 15 & 3.3 \\
\hline Chemistry & 14 & 3.1 \\
\hline Political Science & 14 & 3.1 \\
\hline All other subjects* & 140 & 31.2 \\
\hline Total & 450 & $100 \%$ \\
\hline
\end{tabular}

*All other subjects have $\leq 3 \%$ of total titles purchased.

Table 1 and Table 2 outline patron use by subject. Subjects were assigned by one of the authors. Due to the number of multidisciplinary titles, some OSUL subject specialists did not agree with the more than 40 subject assignments made. However, the assignment of subjects between Test 1 and Test 2 should be relatively uniform because they were assigned by the same person.

Data show that the unmediated ebrary Academic Complete database in Test 2 resulted in 
higher usage of social science and humanities titles. Data also show that the number of subjects viewed in Test 2 was more diverse than in Test 1 . All subjects less than or equal to 3\% of the total titles viewed represent $43.7 \%$ in Test 2, but only $31.2 \%$ in Test 1 . Again, this may be a function of the criteria used to create the Test 1 database. Both tests took place during comparable weeks in fall and winter quarter. No advertising was done for either test, so the increase in use can be attributed to the larger number of titles in the Test 2 database and to the fact that Test 2 counted all titles viewed, not just those exceeding the ten "activity" trigger in Test 1.

TABLE 2 Test 2 Titles Viewed by Subject

\begin{tabular}{|l|r|r|}
\hline Subjects Viewed & No. of Titles Viewed & \% of All Titles Viewed \\
\hline Education/Physical Education & 189 & 15.2 \\
\hline Business/Economics & 105 & 8.5 \\
\hline Health Sciences & 94 & 7.6 \\
\hline English & 87 & 7.0 \\
\hline Sociology/Social Work & 51 & 4.1 \\
\hline History & 49 & 3.9 \\
\hline Psychology & 49 & 3.9 \\
\hline Political Science & 39 & 3.1 \\
\hline Biological Sciences & 37 & 3.0 \\
\hline All other subjects* & 542 & 43.7 \\
\hline Total & 1,242 & $100 \%$ \\
\hline
\end{tabular}

$*$ All other subjects have $\leq 3 \%$ of total titles viewed.

\section{USE OF E-BOOKS BY IMPRINT DATE}

The Test 1 database was supposed to be restricted to 2007 to 2009 imprints, although the sample had earlier imprints, as noted. Print edition dates were later assigned to Test 1 data to ensure accuracy and comparability with Test 2 . The error in creating the sample revealed that patrons, who saw only the accurate MARC record imprint dates in the catalog, were knowingly using older imprints. In Test $1,10 \%$ of the titles purchased were published from 1987 to 2006 and $28 \%$ were published in $2007,32 \%$ in 2008, and $31 \%$ in 2009. The imprint range in Test 2 was much broader, ranging from 1866 to 2009, due to inclusion of backlist titles. Table 3 lists the imprint range of the 1,242 titles viewed by patrons in Test 2.

Table 3 shows that there was still interest in older books. Indeed, the number of books viewed (542) from 2000 to 2004 exceeded the number (513) from 2005 to 2009 . However, because of the differing total number of books available in each range, the percentage of older books viewed was consistently lower than the percentage of newer books viewed. These data show that imprint date is a predictor of patron use of e-books. 
TABLE 3 Test 2 Patron Use by Imprint Year

\begin{tabular}{|l|r|r|r|r|}
\hline Imprint Year & $\begin{array}{c}\text { No. of Titles in } \\
\text { Database }\end{array}$ & $\begin{array}{l}\text { \% of All Titles } \\
\text { in Database }\end{array}$ & $\begin{array}{l}\text { No. of Titles } \\
\text { Viewed by } \\
\text { Patrons }\end{array}$ & $\begin{array}{l}\text { \% of Titles } \\
\text { Viewed by } \\
\text { Patrons }\end{array}$ \\
\hline $1866-1989$ & 923 & 2.1 & 19 & 2.06 \\
\hline $1990-1994$ & 1,674 & 3.8 & 29 & 1.73 \\
\hline $1995-1999$ & 6,136 & 14.0 & 139 & 2.27 \\
\hline $2000-2004$ & 21,365 & 49.0 & 542 & 2.54 \\
\hline $2005-2009$ & 13,563 & 31.1 & 513 & 3.78 \\
\hline Totals & 43,661 & $100 \%$ & 1,242 & 2.84 \\
\hline
\end{tabular}

\section{TEST 1 AND TEST 2 RESULTS BY PUBLISHER TYPE}

Test 1 excluded a substantial number of publishers, some because OSUL acquired their titles through OhioLINK group purchases (e.g., Springer) and some because of the level or type of titles published. Many smaller presses were excluded to cut the overall number. Patron use by publisher type for Test 1 was, therefore, a factor of the set of records provided to users. Results reflect this: trade publishers including medical publishers (79\%), university presses $(20 \%)$, associations and organizations $(1 \%)$, and small publishers $(<1 \%)$. In Test 2 , when the entire ebrary Academic Complete database was used, results were as follows: trade publishers including medical publishers (47\%), university presses (33\%), associations and organizations (15\%), and small publishers $(6 \%)$. This distribution of types of publishers in Test 2 reflects patrons' needs more accurately than the distribution in Test 1.

TABLE 4 Categories of Titles Purchased in Test 1 or Viewed in Test 2

\begin{tabular}{|l|r|r|}
\hline Type of Work & $\begin{array}{c}\text { Test 1: No. and \% } \\
\text { of Titles Purchased }\end{array}$ & $\begin{array}{c}\text { Test 2: No. and \% } \\
\text { of Titles Viewed }\end{array}$ \\
\hline Intermediate-advanced & $230(51.1 \%)$ & $734(59.1 \%)$ \\
\hline Introductory & $67(14.9 \%)$ & $364(29.3 \%)$ \\
\hline Professional & $41(9.1 \%)$ & $24(2.0 \%)$ \\
\hline Textbooks/all levels & $38(8.4 \%)$ & $34(2.7 \%)$ \\
\hline General/reference & $21(4.7 \%)$ & $10(0.8 \%)$ \\
\hline Multidisciplinary & $21(4.7 \%)$ & $31(2.5 \%)$ \\
\hline Testing/study aids & $21(4.7 \%)$ & $17(1.4 \%)$ \\
\hline Serial volumes & $7(1.5 \%)$ & $14(1.1 \%)$ \\
\hline Career materials & $4(0.9 \%)$ & $1,242(100 \%)$ \\
\hline Totals & $450(100 \%)$ &
\end{tabular}

OSUL librarians were interested in knowing the types or categories (i.e., audience level, treatment) of e-books used by patrons. These categories, however, were not assigned by ebrary, and there were insufficient resources to research each title, so one of the authors subjectively assigned categories to the 450 titles purchased in Test 1 and the 1,242 titles viewed by patrons in Test 2 (see Table 4). The textbook category, if it was not clear from the title, was assigned to any title that had a high number of subsequent editions.

\section{NUMBER OF USER LOGINS AND AMOUNT OF E-BOOK READ}

Test 1 data (see Table 5) show that of the 450 titles purchased, patrons viewed a total of 18,567 pages, of which 11,866 were unique pages; 2,791 pages were printed and 193 pages were 
copied for a total of 21,551 "activities" (total activities = pages viewed + pages printed + pages copied). The highest number of pages viewed from a single title was 356 pages. The average number of activities per title was 48 . This level of use suggested more than casual browsing.

TABLE 5 Number of Activities for Titles in Test 1

\begin{tabular}{|l|r|}
\hline Titles purchased $(\geq 10$ activities $)$ & 450 \\
\hline Pages viewed & 18,567 \\
\hline Pages printed & 2,791 \\
\hline Pages copied & 193 \\
\hline Total activities & 21,551 \\
\hline Average activities per title & 48 \\
\hline
\end{tabular}

TABLE 6 Number of Activities for Titles in Test 2

\begin{tabular}{|l|r|}
\hline Titles viewed ( $\geq 1$ activity) & 1,242 \\
\hline Pages viewed & 44,442 \\
\hline Pages printed & 6,123 \\
\hline Pages copied & 304 \\
\hline Total activities & 50,889 \\
\hline Average activities per title & 41 \\
\hline
\end{tabular}

Test 2 included data on all 1,242 titles viewed (see Table 6). It should be noted that 618 $(50 \%)$ of the titles had fewer than ten activities, a use level not counted in Test 1 . The other 624 titles, with ten or more activities, however, showed heavy use, including 16 titles in the range of 500 to 2,373 activities. The most often used title, a 1999 imprint, had 1,787 pages viewed and 581 pages printed over 148 login sessions.

There was concern that a single patron could trigger purchase of an excessive number of titles. Although it was not possible to identify whether one or more individuals accessed a title in either test, it was possible to count activity (viewed, copied, printed) in Test 1 and to count the number of login sessions plus activity in Test 2. A review of titles in both tests showed that no more than two books on the same subject were triggered or accessed on any given day, so this concern appears unfounded.

\section{OSUL AND OHIOLINK HOLDINGS OF PATRON-DRIVEN ACCESS PURCHASES}

Test 1 resulted in 450 titles purchased, which were then searched in the OSUL and OhioLINK catalogs to determine whether sufficient print copies were already available, a figure set at OSUL as five available circulating copies in OhioLINK. Nine percent of the purchased e-books had no holdings in OhioLINK; $65 \%$ had zero to four available copies and would have met OSUL's criteria for firm orders. The "ineligible" $35 \%$ resulted from the inability to remove duplicates before the tests.

To see whether OSUL patrons continued to use older print editions because newer editions had not been purchased until the patron-driven access test, the 450 purchased e-books were searched to see whether OSUL held an earlier print edition. In 42 cases, an earlier print edition was found; when the circulation records of these items were examined, 28 of them had circulated in the last two years. These recently circulated print editions were on average 12 years older than the 
e-book editions purchased by patrons during the patron-driven access test, showing that OSUL patrons continued to use outdated print editions before later electronic editions were purchased and raising concerns about currency of the collections.

\section{SUBJECT LIBRARIANS' COMMENTS ON PATRON-DRIVEN ACCESS PURCHASES}

The authors polled subject librarians on whether they would have used their subject funds to buy titles purchased by patrons in Test 1 . Most agreed they would have, but several concerns were raised. Some subject librarians commented on the problem of duplication, and the authors agreed that an ongoing patron-driven access program must have a way to exclude titles already owned in print to save money for unique content. One librarian was concerned with imprint dates: "The 2009 titles would be likely candidates for purchase, but earlier out-of-date titles might not have been included. From my perspective, currency is of prime value when selecting electronic copy." This comment was of interest to the authors because test data showed that OSUL patrons were using both pre-2007 e-books and even older print editions, because they were available for discovery in the catalog. The authors do not agree that e-books published prior to 2009 are out of date, any more than a pre-2009 print title is necessarily out of date. The authors see this comment as an example of differing expectations for e-books and for print books. Even though content was identical, the delivery system generated differing expectations.

Another concern was funding and whether book funds should be used for so many different levels of materials. The authors are concerned that, if subject funds are limited, they would be used exclusively for upper-level research materials. The entire materials budget is insufficient to cover upper-level research material to support all of OSU's 160 major programs and 63,200 students at a comprehensive level; the expertise of the subject librarian is vital in selecting the best new and retrospective items to support patrons' needs. The authors' position is that lower-level undergraduates, especially freshmen, would be underserved if only advanced titles were purchased. New undergraduates are the population least likely to wait for a book to be borrowed from another OhioLINK library, even if they are aware that borrowing is an option. Undergraduates may especially benefit from a patron-driven access model that purchases "hot topic" or introductory books for term papers with short deadlines. Instant online access is a method familiar to younger students.

\section{ROLE OF COLLECTION DEVELOPMENT LIBRARIANS IN THE AGE OF PATRON-DRIVEN ACCESS}

The potential for a gap between the collection building philosophy of librarians and the immediate information needs of freshmen, undergraduates, and other library users is the crux of the paradigm shift from librarian-mediated to patron-initiated purchasing. Patrons in both tests were using materials at point of need. These included lower-level, introductory, and cross-disciplinary works as well as more focused upper-level and professional-level works. Subject librarians, on the other hand, generally focus on using finite funds to buy works of high quality to cover subjects needed to support teaching and research. There is a real difference between building a balanced collection for the future and giving patrons what they want now. There is a realistic concern that patrons, in buying for immediate need, will change the nature of academic collections over time, generating excessive amounts of purchases in one area to the detriment of building a balanced collection. Patron-initiated collection development might also 
polarize collection levels between introductory works and narrowly focused research materials with less variation in between. How many of these concerns are real can only be determined through further study.

The question of purchasing books in interdisciplinary areas or introductory level publications will continue to be a factor in the paradigm shift from librarian-mediated to patron-initiated collection development. As Nora Rawlinson noted in her 1981 article, "Give 'Em What They Want!" a "book of outstanding quality is not worth its price if no one will read it" (Rawlinson, 2188). Certainly, a patron-driven access model gives patrons what they want. The question is whether a library can afford to pay for what patrons want using currently existing patron-driven access business models. For example, during Test 1, OSUL patrons triggered purchases at the rate of about $\$ 1,150$ per day over 37 days from a database of about 16,000 e-books. Extrapolating those figures, an OSUL patron-driven access program would cost about $\$ 418,000$ per year. It is unlikely that OSUL subject libraries would be willing to turn such a large proportion of the acquisitions budget over to patrons when they already feel their budgets are insufficient.

Are collection development librarians obsolete in the age of patron-initiated acquisitions? Considering the realities of the e-book marketplace, the answer is a resounding "no." Even the largest e-book aggregators have rights to distribute only a fraction of the titles published each year in the United States. The content available through patron-driven access programs, although valuable in fulfilling immediate need, is a small subset of what is published. An academic research library requires more content than current e-book aggregators can provide, just as it requires more content than a single domestic approval plan can provide. The building of an academic research library is still dependent on the expertise of subject librarians.

\section{CONCLUSION}

A paradigm shift is underway to allow greater patron input into e-books acquired by academic libraries based on use. This can be seen through ILPOD and patron-driven acquisition programs. The pilot programs at OSUL examined two ebrary e-book tests. Some of the findings showed that patrons in the sciences, social sciences, and humanities were all active users of e-books during the tests; imprint date was a major predictor of e-book use, although many older imprints showed high usage; patron-triggered purchases varied by level from introductory works, study guides, and multidisciplinary titles to advanced professional literature; and the majority of titles purchased as a result of patron use showed more than one login session and relatively high use.

The findings also point to issues that need to be addressed in the marketplace and by individual libraries: if patron-driven access e-book programs are to be sold to libraries, the amount of patron use that triggers a purchase must be set far higher than present models; patron-driven access products must have real-time monitoring of use and ongoing expenditures to prevent runaway costs; libraries will need to restrict the number and type of titles offered to patrons and develop some model of how to do this; and libraries will want to set priorities for the role patron-initiated purchasing will play in their overall acquisitions program.

The library of the electronic age should provide both the option to "give "em what they want now" and to acquire items that may be needed later. To ignore an immediate patron need is to go against the library's role to support its constituents. To provide only immediately needed items is to ignore the reality that some just-in-case content must be purchased, otherwise it will not be 
available when it is needed.

\section{REFERENCES}

Allen, Megan, Suzanne M. Ward, Tanner Wray, and Karl E. Debus-Lopez. 2003. Patron-focused services in three US libraries: Collaborative interlibrary loan, collection development and acquisitions. Interlending \& Document Supply 31(2): 138-141.

Chan, Gayle Rosemary Y. C. 2004. Purchase instead of borrow: An international perspective. Journal of Interlibrary Loan Document Delivery and Information Supply 14: 23-38.

Comer, Alberta, and Elizabeth Lorenzen. 2005. Biz of ACQ-Is purchase-on-demand a worthy model? Do patrons really know what they want? Against the Grain (February): 75-78.

Perdue, Jennifer, and James A. Van Fleet. 1999. Borrow or buy? Cost-effective delivery of monographs. Journal of Interlibrary Loan, Document Delivery \& Information Supply 9(4): 19-28.

Rawlinson, Nora. 1981. “Give 'em what they want!” Library Journal 106(20): 2188-2190.

Ward, Suzanne M. 2002. Books on demand: Just-in-time acquisitions. Acquisitions Librarian 27: 95-107.

Ward, Suzanne M., Tanner Wray, and Karl E. Debus-Lo'pez. 2003. Collection development based on patron requests: Collaboration between interlibrary loan and acquisitions. Library Collections, Acquisitions, and Technical Services 27(2): 203-213.

Way, Doug. 2009. The assessment of patron-initiated collection development via interlibrary loan at a comprehensive university. Journal of Interlibrary Loan, Document Delivery \& Electronic Reserve 19(4): 299-308.

Zopfi-Jordan, David. 2008. Purchasing or borrowing: Making interlibrary loan decisions that enhance patron satisfaction. Journal of Interlibrary Loan, Document Delivery \& Electronic Reserve 18(3): 387-394. 